\title{
The Impact of Transportation Infrastructure on Export Trade: Evidence from 31 Provinces in China
}

\author{
Lei WU* and Rong KANG* \\ Northwest University, Xi'an, China; 18904603020@163.com; kangrong@nwu.edu.cn \\ * Corresponding author: 18904603020@163.com; kangrong@nwu.edu.cn
}

\begin{abstract}
This paper uses data from 31 provinces in China to test the impact of transportation infrastructure level on China's regional export trade. The regression results show that: the improvement of transportation infrastructure level has a positive impact on regional export trade; through the heterogeneity analysis of transportation infrastructure improvement on regional export trade, it is found that compared with the southern region, the improvement of transportation infrastructure level has a more obvious impact on the export trade of the northern region; compared with the western region, the improvement of transportation infrastructure has a more obvious impact on the export trade of the eastern and central regions; after China's accession to the World Trade Organization, the improvement of transportation infrastructure has a more obvious impact on regional export trade. Further discussion found that the improvement of transportation infrastructure is conducive to improving regional transportation efficiency, thus promoting the development of regional export trade. On the basis of the research conclusion, this paper puts forward the corresponding policy suggestions to better play the role of transportation infrastructure in regional export trade, so as to further promote the development of China's foreign export trade.
\end{abstract}

Keywords: transport infrastructure; highway; railway; export

JEL Classification: C51; F14; O18

\section{Introduction}

The improvement of transportation infrastructure is conducive to reducing transportation costs, to promoting regional trade and economic growth. Since the 1990s, China has carried out large-scale transportation infrastructure construction. From 1978 to 2019, China's railway mileage increased from $51,700 \mathrm{~km}$ to $139,900 \mathrm{~km}$, and China's highway mileage increased from $890,200 \mathrm{~km}$ to 5,012,500 km. As shown in the figure below, Figure 1 shows the growth trend of railway mileage, and figure 2 shows the growth trend of highway mileage.

At the same time, China's export trade is also growing at a high speed. From 1978 to 2019, China's exports increased from US \$9,475 million to US \$2,499,482 million. In 2015, China's exports of goods accounted for $20.49 \%$ of GDP. As shown in Figure 3, since the reform and opening up, especially after China's accession to the World Trade Organization, China's export trade as a whole has been in a state of rapid growth. Export trade has always been an important force in promoting China's economic development. Does the improvement of transportation infrastructure promote regional export trade? Theoretically, the answer is yes. The 


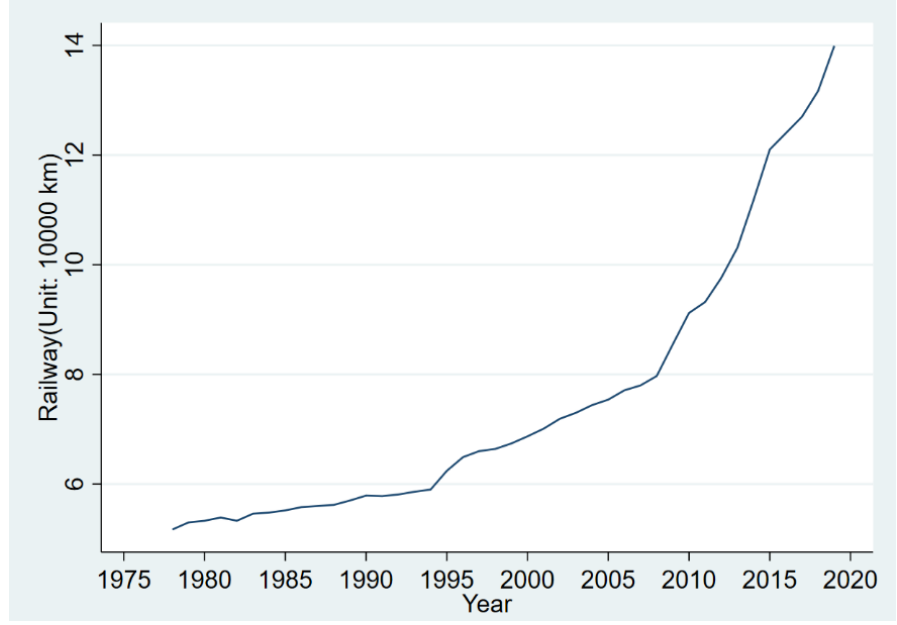

Figure 1. Growth trend of Railway mileage since reform and opening up

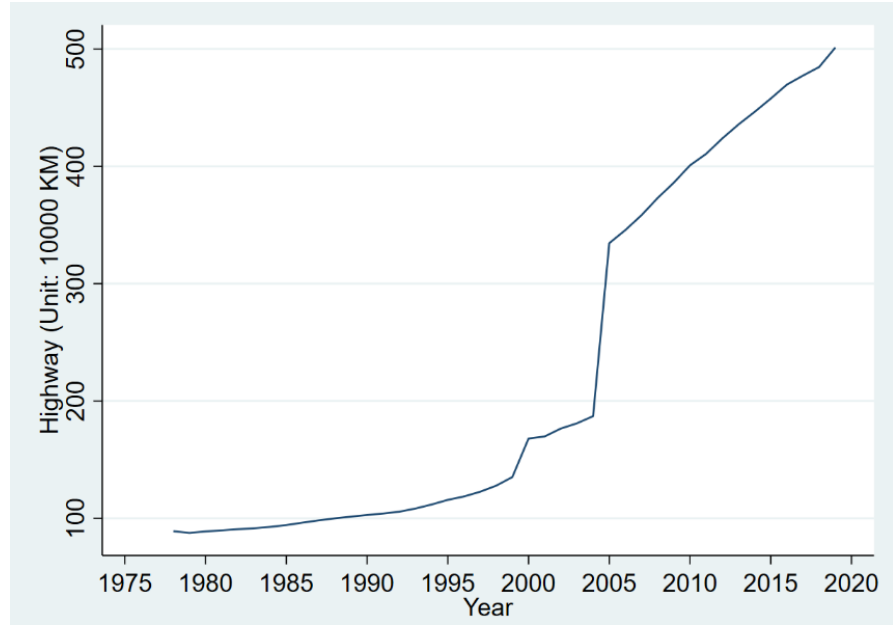

Figure 2. Growth trend of Highway mileage since reform and opening up

improvement of transportation infrastructure will reduce the transportation cost from inland areas to border and port, promote the trade between regions, and enhance the competitiveness of domestic products in the international market. Based on the relevant data of 31 provinces in China, this paper researches the impact of the improvement of transportation infrastructure on China's export trade, and distinguishes the importance of transportation infrastructure on the export trade of different regions by analyzing the heterogeneity of the impact of the improvement of transportation infrastructure on China's regional export trade. On this basis, this paper provides effective policy recommendations on how to improve the level of regional export trade, balance regional export differences and promote regional economic development by improving the transportation infrastructure in the new era.

\section{Literature Review}

Transportation infrastructure is the necessary public goods in the process of economic development, and it is the leading factor to achieve economic growth. Many scholars have done a lot of research on export trade and economic growth around the improvement of transportation infrastructure. 


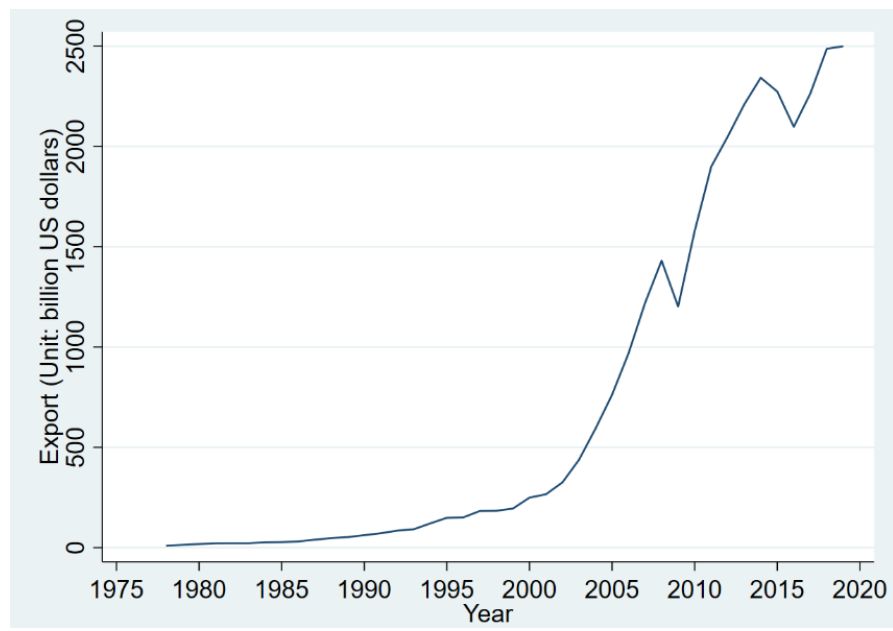

Figure 3. Growth trend of China's export trade since the reform and opening up

Trade cost is one of the important factors affecting bilateral trade. High transportation cost will significantly reduce the trade advantage brought by geographical location (Raballand et al., 2005). Transportation infrastructure is the key to determine the transportation cost (Limão $\&$ Venables, 2001). The improvement of transportation infrastructure quality in both importing and exporting countries plays an important role in the development of international trade. Shi et al. (2018) believe that transportation infrastructure can reduce negotiation cost, time cost and logistics cost, and strengthen the connection of global economic activities. Glaeser and Kohlhase (2003) found that the railway reduced the land transportation cost through the US data inspection. The improvement of transportation infrastructure can make the originally separated regions and markets connected, thus stimulating the generation and growth of trade (Martínez \& Suárez, 2005). Persson (2011) found that the export of heterogeneous products and homogeneous products will increase by $0.7 \%$ and $0.4 \%$ respectively when the transaction cost of export decreases by $1 \%$.

The improvement of transportation infrastructure can also improve transportation efficiency, promote regional export trade and economic growth. Zhou and Zheng (2012) found that China's railway speed increase increases the per capita GDP growth rate by about 3.7\%. Gong and Yin (2016) found that the shortening of railway transportation time and distance can effectively improve the export trade efficiency of China's provinces and cities.

In China's macro level, At the macro level, Liu and $\mathrm{Hu}$ (2010) found that transportation infrastructure plays a significant role in promoting China's economic growth; $\mathrm{Xu}$ et al. (2016) as well as Zhang (2018) found one belt, one road transport infrastructure has positive effects on the improvement of the import and export trade and the regional structure of the relevant countries. The improvement of transportation infrastructure can reduce logistics costs and shorten transportation distance, thus reducing trade costs and promoting trade and economic growth (Liu \& Liu, 2011; Martincus, 2017; Bai \& Ji, 2018). Wang and Huang (2017) investigated the impact of transportation infrastructure on export trade from the perspective of time sensitivity based on the data of China industrial enterprise database from 1998 to 2007, and found that the time sensitivity of different export industries is very different, and the time sensitivity of high-tech industry is the highest. Xu et al. (2012) found that road transportation 
cost and port efficiency are the main factors affecting China's trade expansion. Liu and Shao (2018) found that the improvement of transportation infrastructure inhibited the export trade of enterprises, but promoted the development of domestic trade. There are also many papers studying on the impact of logistics performance (Wang et al., 2018) and port development (Deng, 2016; Wei \& Li, 2017) on export trade.

Through the above research, it is found that the improvement of transport infrastructure can reduce trade costs and improve transport efficiency, thus promoting regional trade growth and regional economic growth. Most of the existing studies focus on the impact of transport infrastructure improvement on the overall trade growth and economic growth, while a few focuses on the temporal and spatial differences of the impact of transport infrastructure improvement on export trade. Based on the analysis of the impact of the improvement of transportation infrastructure on China's export trade, this paper studies the differences of the impact of the improvement of transportation infrastructure on China's export trade between the north and the south, the East, the middle and the west, and before and after China's accession to the World Trade Organization, and analyzes whether the improvement of transportation infrastructure improves the transportation efficiency, so as to promote the development of export trade development.

\section{Methodology}

\subsection{Model Building}

In view of the vital role of transportation infrastructure in promoting local economic development and trade, this paper examines the impact of transportation infrastructure level on China's export trade. This paper selects the provincial panel data of 31 provinces, autonomous regions and municipalities in China from 1997 to 2017 to evaluate the impact of transportation infrastructure level on China's export trade from two aspects: the total regional export volume and the proportion of regional total export in the regional unit output value. The model is set as follows:

$$
Y_{i t}=\alpha_{0}+\alpha_{1} \text { Lnmileage }_{i t}+\sum \text { Control }_{i t}+\mu_{i}+\sigma_{t}+\varepsilon_{i t}
$$

In the above formula, $Y_{i t}$ represents the export trade level of each region. This paper uses the total export trade volume of each region and the export trade volume per unit GDP

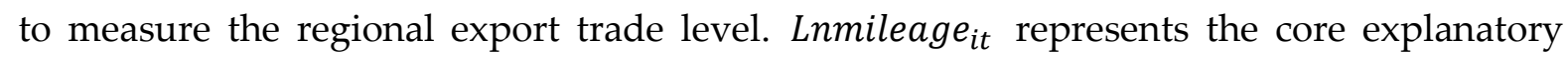
variables, that is the sum of highway mileage and railway mileage; Control $_{i t}$ represents a series of control variables that affect the export trade of provinces; $\mu_{\mathrm{i}}$ and $\sigma_{\mathrm{t}}$ represent the fixed effect of province and year respectively; $\varepsilon_{\text {it }}$ is a random disturbance term.

\subsection{Data Resources}

This paper uses the relevant data of 31 provinces, autonomous regions and municipalities in China from 1997 to 2017, all of which are from China's Province Statistical Yearbook and the official website of the National Bureau of Statistics. Because of the disunity of units in the indexes, this paper adjusts them by calculation. 


\subsection{Index Selection}

The explanatory variable of this paper is the level of regional export trade, which is measured by two indicators: regional total export trade (Lnexport) and export volume per unit of GDP (Gdpexport). The core explanatory variable of this paper is the level of regional transportation infrastructure, which is measured by the sum of regional highway and railway mileage (Lnmileage). In addition, this paper selects other factors that may affect the level of regional export trade as control variables, including GDP (Lngdp), per capita GDP (Lnpergdp), education funds (Lnedufee), social fixed asset investment (Lnfixed), and the number of industrial enterprises (Lnindustry).

\subsection{Model Hypothesis}

This paper puts forward two hypotheses: (1) The improvement of transportation infrastructure level can promote the growth of regional export trade, and the impact of transportation infrastructure level on regional export trade may have time and space differences. (2) The improvement of transportation infrastructure may promote the development of regional export trade by improving transportation efficiency.

\section{Results}

\subsection{Descriptive Statistics}

First of all, this paper makes descriptive statistical analysis on the selected variables, and proves the scientificity of variable selection through variable calculation method and statistical display. As shown in Table 1, the standard deviation of the selected variables is small, reflecting the characteristics of relatively stable data, which can be used for regression analysis.

Table 1. Descriptive statistical analysis of variables

\begin{tabular}{|c|c|c|c|c|}
\hline Variables & Computing Method & Obs & Mean & Std.Dev \\
\hline Lnexport & $\ln ($ export+1) & 651 & 15.810 & 1.913 \\
\hline Gdpexport & export/GDP & 651 & 0.208 & 0.241 \\
\hline Lnmileage & $\ln ($ highway mileage + railway mileage +1$)$ & 651 & 2.166 & 0.746 \\
\hline Lngdp & $\ln ($ gdp+1) & 651 & 8.678 & 1.293 \\
\hline Lnpergdp & $\ln ($ gdp/population+1) & 651 & 1.138 & 0.577 \\
\hline Lnedufee & $\ln ($ education expenditure+1) & 651 & 14.82 & 1.200 \\
\hline Lnfixed & $\ln ($ fixed assets investment+1) & 651 & 8.031 & 1.451 \\
\hline Lnindustry & $\ln ($ number of enterprises+1) & 651 & 8.530 & 1.319 \\
\hline Lntransport & $\ln ($ the volume of freight transport+1) & 651 & 10.853 & 1.253 \\
\hline Lnturnover & $\ln ($ turnover+1) & 651 & 7.342 & 1.310 \\
\hline
\end{tabular}

\subsection{The Impact of Transportation Infrastructure Level on Export Trade}

In order to evaluate the impact of transportation infrastructure level on export trade, based on formula (1), this paper obtains the benchmark regression results shown in Table 2. 
It can be seen that no matter whether the control variable is added or not, the regression results will not change essentially. Under the significant level of $1 \%$, the increase of highway and railway mileage promotes the growth of regional total export trade and regional unit GDP export trade. This shows that the improvement of transportation infrastructure level can promote the development of regional export trade. The improvement of transportation infrastructure level reduces the barriers of interregional trade and transportation, reduces the cost of trade and transportation, and improves the possibility of interregional trade, thus promoting the development of regional export trade.

Table 2. The impact of transportation infrastructure level on export trade

\begin{tabular}{|c|c|c|c|c|}
\hline & $(1)$ & $(2)$ & $(3)$ & $(4)$ \\
\hline Variables & Lnexport & Lnexport & Gdpexport & Gdpexport \\
\hline Lnmileage & $\begin{array}{c}0.775^{* * *} \\
(0.081)\end{array}$ & $\begin{array}{c}0.579^{* * *} \\
(0.088)\end{array}$ & $\begin{array}{c}0.077^{* * *} \\
(0.020)\end{array}$ & $\begin{array}{c}0.077^{* * *} \\
(0.020)\end{array}$ \\
\hline Constant & $\begin{array}{c}13.175^{* * *} \\
(0.138)\end{array}$ & $\begin{array}{c}3.834^{* *} \\
(1.675)\end{array}$ & $\begin{array}{c}0.043 \\
(0.033)\end{array}$ & $\begin{array}{c}-0.494 \\
(0.383)\end{array}$ \\
\hline Control variable & NO & YES & NO & YES \\
\hline Province fixed effect & YES & YES & YES & YES \\
\hline Year fixed effect & YES & YES & YES & YES \\
\hline Observations & 651 & 651 & 651 & 651 \\
\hline R-squared & 0.911 & 0.918 & 0.257 & 0.379 \\
\hline
\end{tabular}

${ }^{1}$ Standard errors in parentheses; ${ }^{2 *},{ }^{* *},{ }^{* * *}$ are significant at the level of $10 \%, 5 \%$ and $1 \%$ respectively.

\subsection{Heterogeneity Analysis of Transportation Infrastructure Level on Regional Export Trade}

\subsubsection{Regional Differences in the Impact of Transportation Infrastructure Level on Regional Export Trade}

In order to further investigate the difference of the impact of transportation infrastructure level on export trade in different regions, this paper uses the method of sub sample regression to investigate the difference of the impact of transportation infrastructure level on export trade between the South and the North of China and the difference of the impact of transportation infrastructure level on export trade between Eastern, Central and Western China.

This paper divides the north and south of China into 15 and 16 provinces according to China's physical and geographical boundaries, and investigates the differences in the impact of transportation infrastructure on export trade between the South and the North of China. The regression results are shown in Table 3. In Table 3, columns (1) and (3) are the regression results of the impact of transportation infrastructure level on the export trade of the northern region, and columns (2) and (4) are the regression results of the impact of transportation infrastructure level on the export trade of the southern region. It can be found that the improvement of transportation infrastructure level promotes the growth of the total export trade volume of the northern and southern regions at a significant level of $1 \%$, and promotes the growth of the export trade volume per unit GDP of the northern region at a significant level of $1 \%$, but it has no significant impact on the export trade volume per unit GDP of the southern region. The impact of transportation infrastructure level on the export trade of northern and southern regions is different. Through the regression coefficient of the core 
explanatory variables, we can find that the impact of transportation infrastructure level on the export trade of the northern region is more obvious than that of the southern region.

Table 3. The impact of transportation infrastructure level on export trade in North and South China

\begin{tabular}{|c|c|c|c|c|}
\hline & $(1)$ & $(2)$ & $(3)$ & $(4)$ \\
\hline Variables & Lnexport-north & Lnexport-south & gdpexport-north & gdpexport-south \\
\hline \multirow{2}{*}{ Lnmileage } & $\begin{array}{c}0.630^{* * *} \\
(0.133)\end{array}$ & $\begin{array}{c}0.507^{* * *} \\
(0.120)\end{array}$ & $\begin{array}{c}0.090^{* * *} \\
(0.022)\end{array}$ & $\begin{array}{c}0.014 \\
(0.032)\end{array}$ \\
\hline \multirow{2}{*}{ Constant } & $6.876^{* * *}$ & -0.301 & -0.148 & $-2.435^{* * *}$ \\
& $(2.185)$ & $(2.603)$ & $(0.358)$ & $(0.689)$ \\
\hline Control variable & YES & YES & YES & YES \\
\hline Province fixed effect & YES & YES & YES & YES \\
\hline Year fixed effect & YES & YES & YES & YES \\
\hline Observations & 315 & 336 & 315 & 336 \\
\hline R-squared & 0.923 & 0.939 & 0.457 & 0.521 \\
\hline Number of provinces & 15 & 16 & 15 & 16 \\
\hline
\end{tabular}

${ }^{1}$ Standard errors in parentheses; ${ }^{2 *},{ }^{* *},{ }^{* *}$ are significant at the level of $10 \%, 5 \%$ and $1 \%$ respectively.

According to the eastern, central and western regions of China divided by the national development and Reform Commission, 31 provinces in China are divided into 12 eastern provinces, 9 central provinces and 10 western provinces for sub sample regression. The regression results are shown in Table 4 . In Table 4, columns (1) and (4) are the regression results of the impact of transportation infrastructure level on the export trade of eastern region, columns (2) and (5) are the regression results of the impact of transportation infrastructure level on the export trade of central region, and columns (3) and (6) are the regression results of the impact of transportation infrastructure level on the export trade of western region. The results show that the improvement of transportation infrastructure level has significantly increased the regional total export trade volume and regional unit GDP export trade volume of the eastern and central regions, but has no significant impact on the western region. Moreover, the impact of the improvement of transportation infrastructure level on the total export trade volume of the central region is higher than that of the eastern region, while the impact of the improvement of transportation infrastructure level on the export trade volume per unit GDP of the two regions is on the contrary, and the impact of the eastern region is higher than that of the western region. Although the improvement of transportation infrastructure level has no significant impact on the western region, from the sign of regression coefficient, the improvement of transportation infrastructure level can promote the development of export trade in the western region. The differences between the three regions affected by the level of transportation infrastructure may be related to the geographical differences and location differences between the eastern, central and western regions of China, as well as the policy influence since China's reform and opening up. Compared with the western region, the eastern and central regions have natural geographical advantages and location advantages. Since China's reform and opening up, the eastern region is often the first region of China's economic policy. These factors lead to the improvement of transportation infrastructure level in the eastern and central regions of China, which is easier to promote the economic development and export trade level of the region. 
Table 4. The impact of transportation infrastructure level on export trade in eastern, central and Western China.

\begin{tabular}{|c|c|c|c|c|c|c|}
\hline & $(1)$ & $(2)$ & $(3)$ & $(4)$ & $(5)$ & $(6)$ \\
\hline Variables & Lnexport-e & Lnexport-m & Lnexport-w & gdpexport-e & gdpexport-m & gdpexport-w \\
\hline \multirow{2}{*}{ Lnmileage } & $\begin{array}{c}0.433^{* * *} \\
(0.103)\end{array}$ & $\begin{array}{c}0.929^{* * *} \\
(0.271)\end{array}$ & $\begin{array}{c}0.221 \\
(0.186)\end{array}$ & $\begin{array}{c}0.093^{* *} \\
(0.047)\end{array}$ & $\begin{array}{c}0.044^{*} \\
(0.023)\end{array}$ & $\begin{array}{c}0.033 \\
(0.027)\end{array}$ \\
\hline \multirow{2}{*}{ Constant } & 0.708 & $-6.474^{*}$ & $25.909^{* * *}$ & -0.569 & $-1.188^{* * *}$ & $2.664^{* * *}$ \\
& $(2.699)$ & $(3.849)$ & $(3.989)$ & $(1.223)$ & $(0.325)$ & Y.578 \\
\hline Control variable & YES & YES & YES & YES & YES & YES \\
\hline Province fixed effect & YES & YES & YES & YES & YES & YES \\
\hline Year fixed effect & YES & YES & YES & YES & YES & YES \\
\hline Observations & 252 & 189 & 210 & 252 & 189 & 210 \\
\hline R-squared & 0.963 & 0.932 & 0.914 & 0.581 & 0.484 & 0.437 \\
\hline Number of Provinces & 12 & 9 & 10 & 12 & 9 & 10 \\
\hline
\end{tabular}

${ }^{1}$ Standard errors in parentheses; ${ }^{2 *},{ }^{* *},{ }^{* * *}$ are significant at the level of $10 \%, 5 \%$ and $1 \%$ respectively.

\subsubsection{The Impact of Transportation Infrastructure Level on Regional Export Trade before and after China's} Accession to the World Trade Organization

After China's accession to the World Trade Organization in 2001, China's foreign trade development level has been greatly improved, and China's international influence has gradually improved. Taking 2001 as the boundary, this paper analyzes the impact of transportation infrastructure level on regional export trade before and after China's accession to the World Trade Organization. The regression results are shown in Table 5. In Table 5, columns (1) and (3) are the regression results of the impact of transportation infrastructure level on regional export trade after China's accession to the World Trade Organization, and columns (2) and (4) are the regression results of the impact of transportation infrastructure level on regional export trade before China's accession to the World Trade Organization. It can be seen that after China's accession to the World Trade Organization, the improvement of the level of transportation infrastructure has significantly promoted the growth of regional export trade, while before China's accession to the World Trade Organization, the level of transportation infrastructure has no significant impact on regional export trade. This shows that after China's accession to the World Trade Organization in 2001, China's export trade has developed rapidly, so the improvement of transportation infrastructure can significantly promote the development of regional export trade, and release the potential of China's export trade development.

\section{Discussion}

By analyzing the impact of transportation infrastructure level on regional export trade, this paper has a comprehensive understanding of the importance of improving transportation infrastructure level and the differences of its impact on the region. However, the scientific discussion of the results and the test of method application need to be verified by robustness test. On this basis, this paper further discusses the impact of transport infrastructure on transport efficiency, and analyzes the internal mechanism of the impact of the improvement of transport infrastructure on regional export trade. 
Table 5. The impact of transportation infrastructure level on regional export trade before and after China's accession to the World Trade Organization

\begin{tabular}{|c|c|c|c|c|}
\hline & $(1)$ & $(2)$ & $(3)$ & $(4)$ \\
\hline Variables & Lnexport>2000 & Lnexport<2001 & exportgdp $>2000$ & exportgdp $<2001$ \\
\hline \multirow{2}{*}{ Lnmileage } & $0.348^{* * *}$ & -0.032 & $0.046^{*}$ & 0.054 \\
& $(0.116)$ & $(0.347)$ & $(0.026)$ & $(0.061)$ \\
\hline \multirow{2}{*}{ Constant } & -0.053 & 4.533 & -0.598 & -0.393 \\
& $(2.184)$ & $(5.541)$ & $(0.486)$ & $(0.968)$ \\
\hline Control variable & YES & YES & YES & YES \\
\hline Province fixed effect & YES & YES & YES & YES \\
\hline Year fixed effect & YES & YES & YES & YES \\
\hline Observations & 527 & 124 & 527 & 124 \\
\hline R-squared & 0.880 & 0.647 & 0.284 & 0.230 \\
\hline
\end{tabular}

${ }^{1}$ Standard errors in parentheses; ${ }^{2 *},{ }^{* *},{ }^{* *}$ are significant at the level of $10 \%, 5 \%$ and $1 \%$ respectively.

\subsection{Robustness Test}

In order to ensure the robustness of the benchmark regression results, this paper uses the method that all explanatory variables lag one period and replace the core explanatory variables to test the benchmark results again.

All explanatory variables lag one period. The results are shown in Table 6. It can be seen that there is no significant difference between the regression results and the benchmark regression results in Table 2 after all explanatory variables are lagged for one period, which indicates the robustness of the benchmark results in the previous paper.

Table 6. All explanatory variables lag one period

\begin{tabular}{|c|c|c|c|c|}
\hline & $(1)$ & $(2)$ & $(3)$ & $(4)$ \\
\hline Variables & Lnexport & Lnexport & gdpexport & gdpexport \\
\hline \multirow{2}{*}{ L.Lnmileage } & $\begin{array}{c}0.800^{* * *} \\
(0.082)\end{array}$ & $\begin{array}{c}0.615^{* * *} \\
(0.089)\end{array}$ & $\begin{array}{c}0.094^{* * *} \\
(0.019)\end{array}$ & $\begin{array}{c}0.090^{* * *} \\
(0.020)\end{array}$ \\
\hline \multirow{2}{*}{ Constant } & $\begin{array}{c}13.078^{* * *} \\
(0.138)\end{array}$ & $\begin{array}{c}4.511^{* *} \\
(1.753)\end{array}$ & $\begin{array}{c}0.003 \\
(0.033)\end{array}$ & $\begin{array}{c}-0.875^{* *} \\
(0.396)\end{array}$ \\
\hline Control variable & NO & YES & NO & YES \\
\hline Province fixed effect & YES & YES & YES & YES \\
\hline Year fixed effect & YES & YES & YES & YES \\
\hline Observations & 620 & 620 & 620 & 620 \\
\hline R-squared & 0.909 & 0.914 & 0.273 & 0.380 \\
\hline
\end{tabular}

${ }^{1}$ Standard errors in parentheses; ${ }^{2 *}, * *, * *$ are significant at the level of $10 \%, 5 \%$ and $1 \%$ respectively.

Replace the core explanatory variable. Highway and railway freight volume can also measure the level of transportation infrastructure in a region. Therefore, this paper selects the highway and railway freight volume to replace the core explanatory variables, and the regression results are shown in Table 7 . It can be seen that the improvement of transportation infrastructure measured by freight volume has significantly promoted the development of regional export trade, which further proves the robustness of the previous results. 
Table 7. Replace the core explanatory variable

\begin{tabular}{|c|c|c|c|c|}
\hline & $(1)$ & $(2)$ & $(3)$ & $(4)$ \\
\hline Variables & Lnexport & Lnexport & gdpexport & gdpexport \\
\hline \multirow{2}{*}{ Lnmileage } & $\begin{array}{c}\text { g.424***} \\
(0.047)\end{array}$ & $\begin{array}{c}0.322^{* * *} \\
(0.060)\end{array}$ & $\begin{array}{c}0.046^{* * *} \\
(0.011)\end{array}$ & $\begin{array}{c}0.068^{* * *} \\
(0.013)\end{array}$ \\
\hline \multirow{2}{*}{ Constant } & $10.044^{* * *}$ & $5.453^{* * *}$ & $-0.307^{* * *}$ & -0.050 \\
& $(0.484)$ & $(1.766)$ & $(0.116)$ & $(0.396)$ \\
\hline Control variable & NO & YES & NO & YES \\
\hline Province fixed effect & YES & YES & YES & YES \\
\hline Year fixed effect & YES & YES & YES & YES \\
\hline Observations & 651 & 651 & 651 & 651 \\
\hline R-squared & 0.910 & 0.916 & 0.258 & 0.390 \\
\hline
\end{tabular}

${ }^{1}$ Standard errors in parentheses; ${ }^{2 *},{ }^{* *},{ }^{* * *}$ are significant at the level of $10 \%, 5 \%$ and $1 \%$ respectively.

\subsection{The Internal Mechanism of the Impact of Transportation Infrastructure Level on Regional} Export Trade

Most of the existing studies believe that the improvement of transportation infrastructure is conducive to reducing trade costs and improving transport efficiency, so as to promote regional export trade and economic development. In this part, the regional freight turnover is selected to measure the regional transportation efficiency to test the impact of the improvement of transportation facilities on the freight turnover. The results are shown in Table 8. It can be seen that whether or not the control variables are added, the improvement of transportation infrastructure level increases the freight turnover and improves the transportation efficiency at a significant level of $1 \%$. At the same time, the author divides China into different regions in the same way as before. Through regression analysis, it is found that the positive effect of infrastructure improvement on transportation efficiency is better in the northern region than in the southern region, and better in the eastern and central regions than in the western region. This shows that the improvement of transport infrastructure can promote the development of export trade by improving transport efficiency, and the effect of transport infrastructure improvement on transport efficiency is still different between regions in China.

Table 8. The influence of transportation infrastructure on transportation efficiency

\begin{tabular}{|c|c|c|}
\hline & $(1)$ & $(2)$ \\
\hline Variables & turnover & turnover \\
\hline Lnmileage & $\begin{array}{c}0.229^{* * *} \\
(0.087)\end{array}$ & $\begin{array}{c}0.253^{* * *} \\
(0.089)\end{array}$ \\
\hline Constant & $5.885^{* * *}$ & $3.696^{* *}$ \\
& $(0.148)$ & $(1.545)$ \\
\hline Control variables & NO & YES \\
\hline Province fixed effect & YES & YES \\
\hline Year fixed effect & YES & YES \\
\hline Observations & 651 & 651 \\
\hline R-squared & 0.798 & 0.819 \\
\hline
\end{tabular}

${ }^{1}$ Standard errors in parentheses; ${ }^{2 *},{ }^{* *},{ }^{* * *}$ are significant at the level of $10 \%, 5 \%$ and $1 \%$ respectively. 


\section{Conclusions}

Based on the relevant data of 31 provinces in China, this paper examines the impact of transportation infrastructure level on regional export trade. The results show that the improvement of transportation infrastructure will significantly promote the growth of regional export trade, and this result has passed the robustness test. At the same time, through the heterogeneity analysis of the impact of transportation infrastructure level on regional export trade, this paper finds that compared with the southern region, the improvement of transportation infrastructure plays a greater role in the northern region. Because of the geographical advantages and location advantages of the eastern and central regions, as well as the policy advantages of the eastern region, the improvement of transportation infrastructure plays a greater role in the eastern and central regions than in the western regions. Compared with before 2001, after China joined the World Trade Organization in 2001, the improvement of transportation infrastructure can further play its role in regional export trade. Further discussion shows that the improvement of transport infrastructure promotes the development of export trade by improving transport efficiency, and the effect of transport infrastructure improvement on transport efficiency is also different between regions in China. On this basis, this paper puts forward the following policy recommendations.

(1) The rapid development of China's high-speed railway can promote China's economic growth to a new level. The speed increase of China's railways can reduce the time cost and improve the transportation efficiency. The Chinese government should further promote the layout of high-speed railways and enhance the efficiency of regional interconnection.

(2) The effect of transportation infrastructure improvement on China's export in different regions is different. The improvement of transportation infrastructure to promote the development of export trade in Western China needs the joint action of other forces, such as releasing the power of transportation infrastructure improvement to promote the development of export trade in economically backward areas of Western China through industrial support and industrial transfer. For the economically developed areas, the transportation infrastructure has been gradually improved, and the space for improving the transportation infrastructure to promote export trade has been limited. The development of export trade needs to further improve the role of other factors, such as improving the innovation ability of enterprises through technological innovation and promoting the formation of high-value industrial chain.

(3) International trade organization can release the effect of transportation infrastructure on regional export. One band and one road, should be promoted to promote the development of export in the Western China.

Acknowledgments: Special thanks are given to Lynne Chester, Professor of Political Economy at the University of Sydney, and to Anders. Ekeland, expert at the National Statistics Office of Norway, for their advice.

\section{References}

Bai, C. E., \& Ji, D. X. (2018). Transportation infrastructure and export: Evidence from national trunk lines in China. The Journal of World Economy, 41(1), 101-122. https://doi.org/CNKI:SUN:SJJJ.0.2018-01-006 
Deng, W. (2016). An empirical study on the impact of port efficiency on China's export trade. Logistics Sci-Tech, 8. https://doi.org/0.13714/j.cnki.1002-3100.2016.08.027

Glaeser, E. L., \& Kohlhase, J. E. (2003). Cities, regions and the decline of transport costs. Papers in Regional Science, 83(1), 197-228. https://doi.org/10.1007/978-3-662-07223-39

Gong, J., \& Yin, Z. M. (2016). One belt, one road strategy of Railway Construction: A study of trade effects based on stochastic frontier model from the perspective of transportation time and transport distance. Journal of International Trade, 2, 14-25. https://doi.org/CNKI:SUN:GJMW.0.2016-02-002

Limão, N., \& Venables, A. J. (2001). Infrastructure, geographical disadvantage, transport costs, and trade. World Bank Economic Review, 3, 451-479. https://doi.org/info:doi/10.1596/0-1985-0908-1

Liu, S. L., \& Hu, A. G. (2010). Transportation infrastructure and economic growth: From the perspective of regional disparity in China. China Industrial Economics, 4, 14-23. https://doi.org/CNKI:SUN:GGYY.0.201004-003

Liu, B. L., \& Liu, Y. H. (2011). Transportation infrastructure construction and inventory cost reduction of Chinese manufacturing enterprises. China Industrial Economics, 5, 69-79. https://doi.org/CNKI:SUN:GGYY.0.2011-05-009

Liu, Q., \& Shao, Z. (2018). Trade cost effect of transportation infrastructure: Theoretical analysis based on dual economic framework and China's experience. World Economy Studies, 2, 98-112+136. https://doi.org/10.13516/j.cnki.wes.2018.02.009

Martínez, Z. I., \& Suárez, B. C. (2005). Transport costs and trade: Empirical evidence for Latin American imports from the European Union. Journal of International Trade and Economic Development, 14(3), 353-371. https://doi.org/10.1080/09638190500212121

Martincus, C.V., Carballo, J., \& Cusolito, A. (2017). Roads, exports and employment: Evidence from a developing country. Journal of Development Economics, 125, 21-39. https://doi.org/10.1016/j.jdeveco.2016.10.002

Persson, M. (2011). Trade Facilitation and the Extensive Margin. Scottish Journal of Political Economy, 22(5), 658693. https://doi.org/10.1080/09638199.2011.587019

Raballand, G., Kunth, A., \& Auty, R. (2005). Central Asia's transport cost burden and its impact on trade. Economic Systems, 29(1), 6-31. https://doi.org/10.1016/j.ecosys.2005.02.004

Shi. Z. K., Shao, J., \& Pu, Z. N. (2018). Transport infrastructure improvement and productivity growth: Evidence from railway speed increase. The Journal of World Economy, 41(6), 127-151. https://doi.org/CNKI:SUN:SJJJ.0.2012-01-008

Wang, Y. J., \& Huang, Q. (2017). Transport infrastructure quality, time sensitivity and export performance. Journal of Finance and Economics, 43(10), 97-108. https://doi.org/10.16538/j.cnki.jfe.2017.10.008

Wang, D. F., Dong, Q. L., \& Yu, L. X. (2018). One belt, one road: National and regional logistics performance and China's foreign trade potential. China Business and Market, 2. https://doi.org/10.14089/j.cnki.cn113664/f.2018.02.003

Wei, S. J., \& Li, L. M. (2017). Analysis on the influence of port development between China and ASEAN countries on China's export to ASEAN: Gravity model checking based on Panel Data. Social Sciences in Guangxi, 3. https://doi.org/10.3969/j.issn.1004-6917.2017.03.007

Xu, L. Z., Fang, S. C., \& Wang, S. Y. (2012). An empirical study on the impact of China's transportation cost and efficiency on export trade. Systems Engineering-Theory E Practice, 32(5), 1057-1057. https://doi.org/10.3969/j.issn.1000-6788.2012.05.018

Xu, J., Chen. K. M., Yang, S. F., \& Lin, L. J. (2016). The international economic and trade effect of "one belt and one road" transportation infrastructure construction. Asia Pacific economy, 3, 3-11. https://doi.org/CNKI:SUN:YTJJ.0.2016-03-003

Zhou, H., \& Zheng, X. T. (2012). Transport infrastructure quality and economic growth: Evidence from China's railway speed increase. The Journal of World Economy, 1, 78-97. https://doi.org/CNKI:SUN:SJJJ.0.2012-01-008

Zhang. P. F. (2018). One belt, one road Asian trade impact of infrastructure development: An analysis based on the gravity model expansion. World Economy Studies, 6, 70-82+136. https://doi.org/CNKI:SUN:JING.0.201806-008 